\title{
STRATEGIC TRADE POLICY WITH HETEROGENEOUS COSTS*
}

\author{
Dermot Leahy and Catia Montagna \\ University College Dublin and CEPR University of Dundee
}

\begin{abstract}
The paper examines optimal strategic trade policy under a heterogeneous cost oligopoly. The first-best policy involves a structure of firm-specific export subsidies/taxes in which the government favours the most efficient firms only with a sufficiently low social cost of public funds.
\end{abstract}

\section{INTRODUCTION}

Even a casual observation of the world suggests that firms within the same industry differ in their market shares and production costs. The acknowledgement of such interfirm differences raises important issues in the field of trade policy. ${ }^{1}$ The strategic trade policy literature suggests that active intervention may be desirable if domestic firms' profits can be increased at the expense of foreign competitors. ${ }^{2}$ In particular, Neary (1994) considers an international duopoly and shows that policy should favour those industries in which domestic firms have a cost advantage over their foreign rivals. However, he does not

\footnotetext{
* We would like to thank David Collie, Sajal Lahiri, Hassan Molana, Peter Neary, Alasdair Smith, Adrian Wood and an anonymous referee for useful comments. The usual disclaimer applies.

${ }^{1}$ For a closed-economy analysis with heterogeneous firms, see Cowling and Waterson (1976) and Lahiri and Ono (1988) for the oligopoly case, and Montagna (1995) for the monopolistic competition case. For an analysis of how cost heterogeneity affects the welfare effects of trade under monopolistic competition, see Montagna (2000).

${ }^{2}$ See Brander (1995) for a survey of the strategic trade literature.
} 
examine optimal policy when there are heterogeneous domestic firms within industries. ${ }^{3}$

This is the first paper to examine first-best optimal policy for the case in which there are differences in costs between the domestic firms in a particular industry. We ask whether the government should favour higher- or lower-cost firms disproportionately. We show that the answer to this question depends on the social opportunity cost of government funds.

The model is developed and discussed in Section II, and Section III concludes the paper.

\section{THE MODEL}

Consider a model in which a fixed number of home firms, $n$, and $n^{*}$ foreign firms export a homogeneous commodity to a third market. The twice-differentiable inverse demand is:

$$
p(Q), \quad p^{\prime}(Q)=-b(Q)<0,
$$

where $Q$ is total industry sales. Firms have different but constant marginal costs represented by $c_{i}$ for a typical home firm. Profits for the typical home firm from its exports to the third market are:

$$
\pi_{i}=\left(p-c_{i}+s_{i}\right) q_{i},
$$

where $s_{i}$ is a firm-specific export subsidy and $q_{i}$ is the quantity produced by firm $i$. We follow a standard approach in restricting attention to the export market and assume no links with other markets, in order to focus on strategic export policy issues. Only the home government is policy active and its objective function depends positively on the profits of the home firm and negatively on the subsidy payments. It is usually assumed in the strategic trade literature that profits and government revenue have equal weight in the welfare function. There are good reasons for regarding this as a rather special case. For example, the government will typically be unable to finance all of its spending by non-distortionary lump-sum taxation. If it must finance its spending at the margin by distorting taxation, then the opportunity cost of government revenue exceeds unity. Taking this issue into account has important consequences. As the social cost of funds increases, the profit-shifting argument is weakened, given that the government is not willing to trade

\footnotetext{
${ }^{3}$ Collie (1993) and Van Long and Soubeyran (1997) allow for firm heterogeneity. However, both papers restrict attention to the case in which the government gives a (second-best) uniform subsidy to firms. Lahiri and Ono (1998) develop a multicountry oligopoly model with asymmetric costs which provides a general framework in which to analyse the relationship between market shares and welfare.
}

(C) Blackwell Publishers Ltd and the Board of Trustees of the Bulletin of Economic Research 2001. 
off one extra dollar earned in profit with one extra dollar in subsidy payments. ${ }^{4}$ Therefore it is likely that the optimal policy in our model will be sensitive to the social cost of funds. To examine this issue we follow an approach well known in the public finance literature and introduce a parameter $\delta \geqslant 1$ to measure the social cost of funds. ${ }^{5}$ Welfare is thus:

$$
W=\sum_{i}^{n} \pi_{i}-\delta \sum_{i}^{n} s_{i} q_{i}=\sum_{i}^{n}\left\{p-c_{i}+(1-\delta) s_{i}\right\} q_{i} .
$$

We will be concerned with the first-best policy in which the government chooses firm-specific subsidies. ${ }^{6}$ We solve for the subgame-perfect equilibrium of the two-stage game in which the home government chooses the subsidies in stage one. ${ }^{7}$ In stage two, given the vector of subsidies, the firms play Cournot. The first-order condition for a typical home firm is:

$$
\frac{\partial \pi_{i}}{\partial q_{i}}=p-c_{i}+s_{i}-b q_{i}=0 .
$$

The first-order condition for a typical foreign firm takes the same form (apart from it having a zero subsidy).

Assumption 1: Outputs are strategic substitutes for all firms: $1+\alpha_{L} r(Q)>0$, where $r(Q)=b^{\prime} Q / b$ and $\alpha_{L}$ is the market share of the largest (lowest cost) firm in the industry.

The government has $n$ subsidy instruments and $n$ targets in the form of exports for each of the home firms. We can think of the government as choosing the optimal level of exports of each of the home firms taking account of the reactions of the foreign exporters. It effectively chooses the vector of home exports before the foreigners choose their outputs. From the perspective of the government, which enjoys a first-mover advantage, the total change in industry output as a result of a change in $q_{i}$ taking account of the foreign reaction is: $d Q / d q_{i}=1+\sum_{k} d q_{k}^{*} / d q_{i}$, where $q_{k}^{*}$ is the output of a typical foreign firm. Totally differentiate (3) and make use of (4) and of its total derivative to get the following

\footnotetext{
${ }^{4}$ From a national perspective, a dollar of profit will also be worth less than a dollar of subsidy payments if the firm is partly foreign-owned and some of the profits earned are repatriated.

${ }^{5}$ See Lahiri et al. (2000) for a useful discussion of the interpretation and microfoundations of $\delta$.

${ }^{6}$ Of course we are considering the first-best from a national, not a global, perspective. Truly global first-best policy would require removing the oligopolistic distortion.

${ }^{7}$ Our model extends that in Lahiri and Ono (1998) by allowing the government to choose the vector of optimal subsidies. In addition, unlike Lahiri and Ono (1998), we allow for a social cost of funds $\delta \geqslant 1$.
} 
expression for the optimal subsidy:

$$
s_{i}^{\mathrm{o}}=\frac{2-\delta}{\delta} b q_{i}-b \sum_{i}^{n} q_{i}\left(1+\frac{\delta-1}{\delta} \alpha_{i} r\right) \frac{d Q}{d q_{i}},
$$

where $\alpha_{i}$ is the market share of firm $i$. It is instructive to rewrite this in terms of the average subsidy. Sum over the $n$ subsidies and substitute into (5) to get:

$$
s_{i}^{\mathrm{o}}=\bar{s}+\frac{2-\delta}{2(\delta-1)}\left(\bar{c}-c_{i}\right),
$$

where $\bar{s}=(1 / n) \sum s_{i}$ is the average subsidy and $\bar{c}=(1 / n) \sum c_{i}$ is the mean home-country marginal cost. The deviation of the typical firm $i$ 's optimal subsidy from the average subsidy depends on its marginal cost relative to the marginal cost of the average firm in the industry and on the size of the social cost-of-funds parameter. If a particular home firm has a marginal cost that is lower than average, then it will receive a subsidy that is higher than average if and only if $\delta<2$.

Proposition: The home government's optimal firm-specific policy entails a structure of subsidies. Lower-cost firms will receive higher export subsidies only if the social cost of funds is sufficiently low.

Neary (1994) has strengthened the view that there are sectors in the economy that are more valuable than others and they should be targeted by the government. Our result goes further and points to the existence of a comparative advantage in profit-shifting within industries at the firm level. However, this comparative advantage in profit-shifting should be exploited only if the social opportunity cost of the subsidy bill is not too high.

The following is another clear implication of Proposition 1.

Corollary 1: Only when home firms have identical marginal costs, or when $\delta=2$, can the national first-best be achieved with a uniform subsidy.

The average subsidy in (6), which may be positive or negative, can be written as:

$$
\bar{s}^{\mathrm{o}}=\frac{2-\delta}{\delta} b \bar{q}-b \sum_{i}^{n} q_{i}\left(1+\frac{\delta-1}{\delta} \alpha_{i} r\right) \frac{1}{D},
$$

where $D \equiv 1+n^{*}+\left(1-\sum^{n} \alpha_{i}\right) r$ is positive from Assumption 1, and $\bar{q}$ is the average home-firm output. If the average subsidy is negative

(C) Blackwell Publishers Ltd and the Board of Trustees of the Bulletin of Economic Research 2001. 
but $\delta<2$, then lower-cost firms should be taxed less than higher-cost firms. Hence picking winners can be optimal even when firms are taxed.

Corollary 2: At a social cost of funds at or above which the pick-thewinners policy no longer holds $(\delta \geqslant 2)$, the average optimal subsidy is negative.

The proof follows from equation (6) and (7).

The higher the level of $\delta$, the higher is the social opportunity cost of the subsidy bill. When $\delta$ exceeds unity, the government is directly concerned to minimize total subsidy payments. Low-cost firms, as well as having a comparative advantage in rent-shifting, have larger market shares, and hence for given per-unit subsidies contribute more to raising the government's subsidy bill. At sufficiently high levels of $\delta$, the opportunity cost of the subsidy bill dominates the rent-shifting motive and the picking-the-winners policy is reversed.

An interesting issue concerns the size of the social opportunity costs of funds. The empirical literature on the marginal cost of public funds offers a wide range of estimates. ${ }^{8}$ The majority of studies suggest that $\delta$ may lie between 1.15 and 1.5. Thus this evidence supports the pick-thewinners policy.

Finally, note that here we have been assuming that it is optimal for the government to allow all the home firms to export. However, for sufficiently low $\delta$ it will be optimal to prevent some of the higher-cost firms from exporting. In particular, it is easy to show that, for a given distribution of marginal costs, there will be a threshold value of $\delta$ below which it will be optimal to tax the highest-cost firm at a level that will prevent it from exporting. The optimal subsidy for the remaining home firms will then be given by (6), with $\bar{s}$ and $\bar{c}$ interpreted as the average subsidy and marginal cost of firms that the government allows to export positive quantities. The threshold $\delta$ at which all firms will be permitted to export will be lower, the smaller is the gap between the marginal cost of the highest-cost firm and that of the average firm. It follows that when $\delta$ is only marginally above unity, all the firms for which $c_{i}>\bar{c}$ should be taxed at levels so high that they will choose not to export. Ultimately only the lowest-cost firm will be allowed to export. It will then receive a subsidy. Furthermore it is clear that (6) is not well defined for the special case of $\delta=1$. At $\delta=1$ the first-best outcome implies a corner solution in which only the lowest-cost firm receives a subsidy and exports a positive quantity. The remaining firms are taxed out of the export market.

\footnotetext{
${ }^{8}$ See for instance, Ballard et al. (1985) and Fullerton (1991).
}

(C) Blackwell Publishers Ltd and the Board of Trustees of the Bulletin of Economic Research 2001. 


\section{CONCLUSION}

This is the first paper to examine first-best optimal strategic trade policy when firms have heterogeneous costs. We have shown that the first-best policy involves a schedule of firm-specific subsidies and taxes in which the government picks winners only if the social cost of funds is not too high. The need to identify relatively low-cost firms within an industry increases the complexity and informational requirements of the policy. Clearly, these conclusions cast further doubt on the feasibility of implementing a successful strategic trade policy.

\section{REFERENCES}

Ballard, C., Shoven, J. and Whalley, J. (1985). 'General equilibrium computations of the marginal welfare cost of taxes in the United States', American Economic Review, vol. 75, pp. 128-38.

Brander, J. A. (1995). 'Strategic trade policy', in: Grossman, G. and Rogoff, K. (eds), Handbook of International Economics, vol. III. North-Holland, Amsterdam, pp. 1395-455.

Collie, D. (1993). 'Strategic trade policy under asymmetric oligopoly', European Journal of Political Economy, vol. 9, pp. 275-80.

Cowling, K. G. and Waterson, M. (1976). 'Price-cost margins and market structure', Economica, vol. 43, pp. 267-74.

Fullerton, D. (1991). 'Reconciling recent estimates of the marginal welfare cost of taxation', American Economic Review, vol. 82, pp. 302-08.

Lahiri, S. and Ono, Y. (1988). 'Helping minor firms reduces welfare', Economic Journal, vol. 98, pp. 1199-202.

Lahiri, S. and Ono, Y. (1998). 'Asymmetric oligopoly, international trade and welfare: a synthesis', Journal of Economics, vol. 3, pp. 291-310.

Lahiri, S., Nasim, A. and Ghani, J. (2000). 'Optimal second-best tariffs on an intermediate input with particular reference to Pakistan', Journal of Development Economics, vol. 61, pp. 393-416.

Montagna, C. (1995). 'Monopolistic competition with firm specific costs', Oxford Economic Papers, vol. 47, pp. 318-28.

Montagna, C. (2000). 'Efficiency gaps, love of variety and international trade', forthcoming, Economica.

Neary, J. P. (1994). 'Cost asymmetries in international subsidy games: should governments help winners or losers?', Journal of International Economics, vol. 37, pp. 197-218.

Van Long, N. and Soubeyran, A. (1997). 'Cost heterogeneity, industry concentration and strategic trade policies', Journal of International Economics, vol. 43 , pp. $207-20$. 